\title{
Az „ötlet” a gyógynövénykutatás eszköztárában
}

Hohmann Judit

Szegedi Tudományegyetem, Farmakognóziai Intézet, 6720 Szeged, Eötvös u. 6.

e-mail: hohmann@pharm.u-szeged.hu

Az igen szerteágazó gyógynövénykutatás sokféle megközelítést alkalmaz a kutatandó téma kiválasztásában, problémafelvetéseiben. A növényi hatóanyagok izolálása során leggyakrabban kémiai vagy farmakológiai szűrővizsgálatok eredményei vezetik a kutatót az ígéretes növényfajok kijelölésében, esetenként valamilyen természetes vezérmolekula hívja fel a figyelmet egy-egy növényfajra vagy nemzetségre. A népi gyógyászati megfigyelések ugyancsak gyakran szolgálnak kiindulópontként növénykémiai, farmakológiai munkákhoz. A növényanalitika területén valamely kivonat összetétel-vizsgálata vagy egyes termékek standardizálása iránti igényből indulnak ki a kísérletek, esetleg termékhamisítás igazolását vagy cáfolatát célozzák. A természetes anyagok félszintézisével általában hatás-szerkezet összefüggések elemzéséhez szükséges szerkezetileg analóg, új vegyületek vagy vegyületsorozatok előállítását végzik a kutatók.

A gyógynövénykutatás minden területén fontos szerepet játszik az "ötlet”. Hogy jó ötlete szülessen a kutatónak, mindenekelőtt alapos szakmai felkészültségre, széleskörü tájékozottságra, a módszerek és az eszköztár kiváló ismeretére, és nem utolsó sorban jó megfigyelőképességre van szükség. Az ezek alapján születő ötlet olyan kísérletek hajtóereje lehet, amelyek eredeti, új felismerésekhez vezetnek. Az ötlet persze egy hipotézis, feltételezés, amit igazolni kell, tehát valódi értékét a megvalósítás adja.

Jelen előadás olyan témákat kíván bemutatni a gyógynövénykutatás területéről, melyek mindegyikében fontos szerepet játszott valamilyen jó ötlet. Valamennyi téma elindítója és mozgatója a kutatói kreativitás és zsenialitás, amely minden esetben érdekes, új tudományos eredményhez vezetett. 